\title{
THE EXPERIENCE WITH IMPLEMENTATION OF TECHNOLOGY - ENHANCED LEARNING IN TEACHING BACHELORS
}

\author{
Štefan SVETSKÝ
}

\begin{abstract}
Among teachers, the European research policy related to ICT for education is less known.It is commonly equate with eLearning, which is understood more as an educational issue than a technology one. In the context of the FP7 policy for "Technology-enhanced learning", the experiences are presented that were obtained within the "extended" participatory action research when teaching bachelors. "Extended" refers to the fact that the technology system is programmed by the author of this paper. The system consists from the educational software BIKE and a set of informatics tools that are developed and applied according to the immediate needs in order to automate the creation of teaching content, communication and processes in the classroom. This approach is focused on the personal support of a teacher, which plays key role in teaching. Several examples of pilot applications implemented into teaching of bachelors are presented. As well, some technological, educational and terminological aspects of computer supported teaching and learning are discussed.
\end{abstract}

Key words: technology-enhanced learning, computer assisted learning, automation of teaching and learning processes, personalised support of teacher, database technologies

\section{SKÚSENOSTI S IMPLEMENTÁCIOU TECHNOLOGY - ENHANCED LEARNING VO VÝUČBE BAKALÁROV}

Resumé: Európska polititika výskumu počítačovej podpory vzdelávania je medzi učitel'mi menej známa. V praxi sa obvykle zamieňa s eLearningom, ktorý sa chápe skôr ako pedagogická než technologická záležitost'. V kontexte politiky 7. rámcového programu v IKT pre tzv. „Technologyenhanced learning" sa prezentujú skúsenosti získané v rámci "rozšíreného" participačného akčného výskumu implementácie počítačovej podpory do výučby bakalárov. Pod "rozšíreným" sa myslí skutočnost', že autor tohto príspevku programuje systém, ktorý pozostáva z edukačného softvéru BIKE a sady informatických nástrojov, ktoré sa aplikujú podla okamžitej potreby na automatizáciu tvorby obsahu, komunikácie a procesov $\mathrm{v}$ triede $\mathrm{s}$ ciel'om zvýšit' produktivitu duševnej práce a kvalitu výučby. Prezentujú sa viaceré príklady pilotných aplikácií zavedených do výučby bakalárov. Taktiež sa diskutujú niektoré technologické, didaktické a terminologické aspekty počítačovej podpory.

Kl'účové slova: technológiou zdokonal'ované vzdelávanie, počítačová podpora vzdelávania, automatizácia výučby, personalizácia podpory učitel'a, databázové technológie

\section{1 Úvod}

Hoci sa v oblasti IKT dosiahli v uplynulých rokoch enormné pokroky, treba mat' stále na pamäti, že počítače neboli pôvodne vymyslené pre vzdelávanie. Taktiež treba vziat' do úvahy, že výučba úzko súvisí s transformáciou informácií. Z hladiska programovania je zase vel'mi obtiažne riešit' spracovávanie neštruktúrovaných, neurčitých informácií a vedomostí a to $\mathrm{v}$ procesoch vzdelávania, ktoré rovnako nie sú jasne definované a štruktúrované. V politike výskumu EU sa $\vee$ 7. rámcovom programe pre oblast' IKT 7 zarad'uje počitačová podpora vzdelávania do kategórie ,technology-enhanced learning“. Prakticky to znamená, že sa prioritne rieši technológia, resp infraštruktúra a predpokladá sa automaticky, že bude mat' aj „správny“ pedagogický účinok. Nakol’ko vzdelávanie je vysoko sofistikovaný a individuálny proces, takýto technologicky preferovaný prístup logicky nemôže vyriešit' bežné didaktické postupy, komunikáciu a d'alšie špecifické potreby výučby.

$\mathrm{V}$ bežnej praxi existuje vel'a rôznych jednoúčelových softvérov, ale neexistuje žiadny univerzálny softvér, ktorý by mohol učitel' používat' súčasne na podporu viacerých druhov činností. Ambíciou niekol'koročného výskumu implementácie počítačovej podpory do výučby bakalárov na Materiálovotechnologickej fakulte so sídlom v Trnave bolo vyvinút' softvér, ktorý by mohol užívatel', či už učitel' alebo študent, používat' ako osobný informatický nástroj a to bez potreby špeciálnych informatických 
zručností. Výsledkom je vyvinutý systém „technology - enhanced learning“, ktorého základom je predpogramované edukačné prostredie BIKE ako aj sada d'alších informatických nástrojov, vrátane virtuálneho učebného priestoru na fakultnom serveri. $\mathrm{V}$ tomto príspevku sa prezentujú ukážky z pilotných riešení zavedených do výučby bakalárov a diskutujú sa s nimi súvisiace problémy.

\section{Technology - enhanced learning}

„Technology-enhanced learning“ (TEL) možno vol'ne preložit' ako „technológiou zdokonal'ované vzdelávanie“. V informačnom systéme EU CORDIS sa uvádza, že ide o oblat' výskumu, ktorá sa zameriava na to ako môžu byt' informačné a komunikačných technológie pouzité na podporu vzdelávania a vyučovania a rozvoj kompetencií $v$ priebehu celého života (http://cordis.europa.eu/fp7/ict/telearn-digicult/te learn_en.html). Myslí sa pod tým podpora všetkých druhov vzdelávacich aktivit prostrednictvom technológie s ciel'om zabezpečit sociálno-technické inovácie pre prax vzdelávania, či už ide o jednotlivcov alebo organizácie, nezávisle na čase, mieste a tempe.

Aj ked' takáto definícia umožňuje pomerne široký výklad, ciele a zameranie výziev 7. rámcového programu, resp. postupy pre podávanie európskych projektov sú $\mathrm{v}$ CORDIS vždy detailne rozpracované v anglických manuáloch o desiatkach až stovkách strán. V posledných výzvach TEL (ciel' ICT-2011.8.1) boli napr. prioritou ,systémy, $v$ ktorých je tútorom človek; vzdelávacie technológie pre vedu, technológiu; výpočtové nástroje posilňujúce kreativitu vo vzdelávacom prostredi“. Očakávaným dopadom bolo uvol'nenie potenciálu jednotlivcov adaptovaním a personalizáciou vzdelávacích technológií. V najnovšej výzve (ciel' ICT-2013.8.2) sú medzi prioritami zaradené vzdelávacie prostredia sintegrovaním IKT; analytika vo vzdelávani a edukačné dolovanie dát. Očakávaným dopadom má teraz byt' rozširovanie IKT vo vzdelávaní, efektívne verejno - súkromné partnerstvá poskytujúce digitálne riešenia na európskej úrovni a taktiež rozširenie trhu saplikáciami IKT pre vzdelávanie [1].

Zo súčasnej politiky EU vo výskume TEL vyplýva, že takáto politika si automaticky vyžaduje spoločný, integrovaný prístup informatikov (informatické nástroje) aj učitel'ov (vzdelávací obsah, učivo, výučba). Preferovanie technológiou - riadeného prístupu preto samo o sebe nepostačuje, ak nie je kombinované $s$ vhodným pedagogicko - riadeným prístupom. Súčasný stav TEL sa však vyznačuje opačným, nevyváženým prístupom, t.j. že sa prioritne rieši technologická stránka, kým pedagogické, resp. didaktické aspekty sa nedoceňujú. Na ilustráciu možno uviest', že $\mathrm{v}$ jednom $\mathrm{z}$ publikovaných prieskumov, aké nástroje TEL sa najčastejšie použivajú na európskych univerzitách, bol ako najfrekventovanejší vyhodnotený vol'ne šíritel'ný softvér Moodle [2]. Tento však patrí do kategórie tzv. systémov manažmentu vzdelávania (Learning Management System, Virtual Learning Enviroments). Pre priamu podporu výučby $\mathrm{v}$ triede nie je vhodný.

Aj ked' TEL je zaradené do informatickej oblasti, určite je každému zrejmé, že riešenie aplikácií pre vzdelávanie je ovel'a náročnejšie, ako riešenie účtovníckych, finančných, či technických systémov. Z literatúry systematicky zameranej na TEL sa napr. v [3] uvádza, že vzdelávanie a nie technológia by malo byt' hnacou silou inovácii. Zdôrazňuje sa o.i. aj téza, že nové technologické vzdelávacie prostredia musia byt' kongruentné s tým, ako sa jednotlivci učia a aká je podstata vzdelávacích úloh. Obdobne zdôrazňuje tento l'udský aspekt TEL aj Derry v [4]. Upozorňuje pritom na fakt, že pri preferovanom technologicky - riadenom prístupe sa vedomosti „viacmenej len predpokladajü“. To potom dáva do súvisu so sklamanim s doterajšími výsledkami riešení TEL v praxi. Tvrdí, že práca $\mathrm{s}$,anonymnými“ vedomostami je vrozpore už so samotnou podstatou vzdelávania. $\mathrm{V}$ tejto súvislosti možno tiež spomenút' kl'účového rečníka R. Meyera na konferencii ICL - IGIP (Villach, 2012), ktorý zdôrazňoval, že nové technológie, ako sú sociálne médiá, on-line prostredia, dial'kovo riadené laboratóriá, môžu ovplyvnit' posun paradigmy $z$ hladiska spôsobu, ako sa informácie prenášajú z mentora na študenta [5]. Ináč povedané, učitel' hrá kl'účovú úlohu a sám si podl'a potreby vyberá a riadi najvhodnejšiu technológiu. Pripomenul aj známu skutočnost', že ak aj učitelia vo svete vyučujú ten istý inžiniersky obsah, technológia a prax použitá $\mathrm{v}$ triedach sa dramaticky líšia podl'a regiónov a kultúry. V tomto duchu Laurillard chápe TEL ako nástroj na riešenie pedagogických inovácií vyslovene na báze edukačne - riadeného prístupu [6]. Táto autorka taktiež zdôrazňuje, že úspešná implementácia TEL na univerzitách si vyžaduje úzku spoluprácu troch subjektov - vývojára, výskumníka a učitela, ktorí sa nie vždy vo všetkom názorovo zhodnú [7]. 
3 Výskum implementácie TEL vo výučbe bakalárov

Výskumom TEL vo výučbe bakalárov sa dlhodobo zaoberajú na Materiálovotechnologickej fakulte STU, pričom t'ažisko výstupov je na Detašovanom pracovisku v Dubnici nad Váhom [8]. Doterajšie skúsenosti ukazujú dôležitost' edukačne - riadeného prístupu už aj v tom, že niektoré aplikácie by sa neboli vôbec naprogramovali, ak by sa neriešili problémy reálnej výučby v triede. Takto vznikla napr. podl'a okamžitej potreby výučby potreba riešit' typizáciu učiva a procesov (kvôli ul'ahčeniu automatizácie), programovat' komunikačné kanály učitel' - študent, virtuálne výpočtové prostredie a d'alšie aplikácie.

Pilotné riešenie počítačovej podpory je znázornené na obr. 1. V l'avej časti obrázka sú uvedené nástroje TEL, ktoré autor tohto príspevku naprogramoval a vyvinul. Základom je predprogramované prostredie BIKE (Batch Information and Knowledge Editor), ktoré umožňuje učitel'ovi a študentom spracovávat' v dávkach vel'ké množstvo informácií a vedomostí (d'alej len vedomostí). Zápisník, je čast' BIKE, ktorý sa inštaluje na počítače $\mathrm{v}$ učebni. S týmito vyvíjanými nástrojmi sa rieši automatizácia, inovácie výučby a buduje sa personalizované učebné prostredie. V pravej časti obrázka je uvedených niekol'ko aplikácií a predmety, pre ktoré sa implementovala počítačová podpora.

Výstupy sa dajú prezerat' internetovými prehliadačmi či už na internete alebo na počítačoch $\mathrm{v}$ triede (aj $\mathrm{v}$ off-line režime). Obrázok ilustruje aj skutočnost', že ide o viacúčelový softvér, resp. systém a že užívatel' má miesto desiatky softvérov $\mathrm{k}$ dispozícii ,všetko v jednom" (all-in-one).

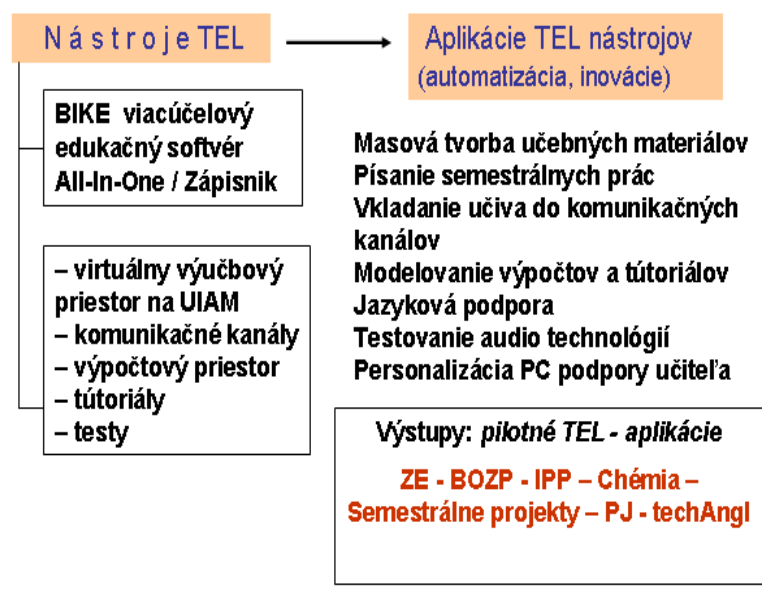

Obr. 1: TEL nástroje, aplikácie a výstupy v rámci automatizácie a inovácii výučby
Schéma tvorby personalizovaného učebného prostredia je uvedená na obr. 2. Malo by z nej byt' jasné, že BIKE spolupracuje s prehliadačmi a operačným systémom Windows (pravá čast'). V l'avej časti je zobrazené virtuálne učebné prostredie, ktorého čast' je na osobnom počítači užívatel'a a niektoré zložky sú na internete (presnejšie na fakultnom serveri UIAM).

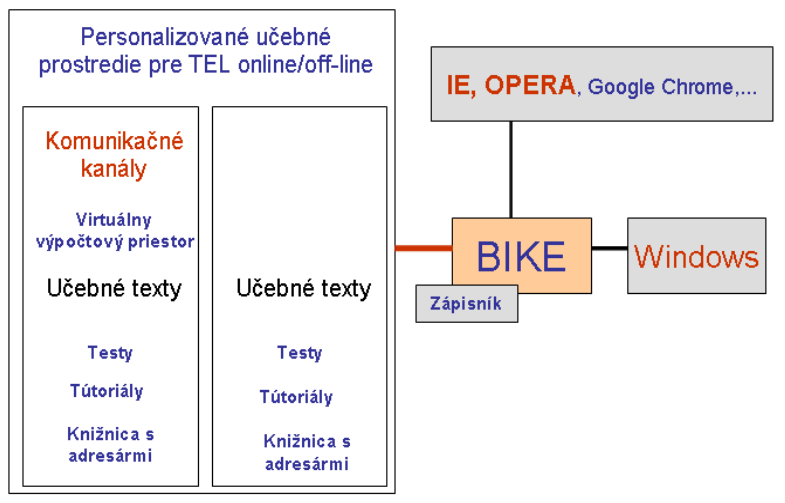

Obr. 2: Schéma tvorby personalizovaného učebného prostredia s pomocou BIKE

K zavedenému systému počítačovej popdory možno ešte uviest', že ide asi o jedno z najlacnejších a najefektívnejších riešení počítačovej podpory jednotlivca, aké vôbec existuje. Okolo roku 2000 by síce išlo o extrémne drahé riešenie, avšak dnes majú univerzity svoje servery, osobné počítače bežia pod Windows a internetové prehliadače sú zadarmo. To ostatné učitelia vedia, pretože sa tým, „živia“. Nespornou výhodou je však to, že učitel' ako užívatel' (rovnako študent, výskumník) si sám určuje spôsob práce a je nezávislý na informatikoch. Samotné riešenie je v zásade „prázdny systém“, ktorý si uživatel' naplńa informáciami a vedomostami. Na počítači autora súčasnosti BIKE obsahuje rádovo tisícku databázových a programových súborov so stovkami položiek užívatel'ského menu. Všetky výstupy do výučby boli paralelne publikované doma aj v zahraničí (EU, USA, Austrália, India). BIKE sa pritom prezentuje ako „nový“, resp. odlišný typ personalizovaného edukačného softvéru, ktorý je alternatívou k tzv. WEB 2.0 technológiám (napr. Moodle). Z pohl'adu jeho autora ide o akýsi doplnkový softvér medzi globálnymi službami na internete a počítačom jednotlivca.

\section{Terminologické problémy implementácie TEL}

Implementácia TEL do výučby je spojená $\mathrm{s}$ viacerými terminologickými nedorozumeniami. TEL sa vel'mi často zamieňa s termínom eLearning, ktorý je $\mathrm{v}$ učitel'skej praxi dlhé roky 
zaužívaný a prirad'uje sa knemu akákol'vek počítačová podpora. Problémy definície eLearningu sú však celosvetové. Detailne túto problematiku rozoberá napr. Littlejohn v [9], kde o.i. poukazuje na skutočnost', že aj rôzne eLearningové asociácie majú odlišný výklad tohto pojmu. Na Oxfordskej univerzite sa s touto otázkou vysporiadali tak, že počnúc školským rokom 2011 - 2012 nahradili pôvodný názov študijného programu ,eLearning“ za „Learning and Technology". Ako dôvod uviedli, že v súčasnosti je termín eLearning už dávno prekonaný a zastaralý. Okrem toho je aj zavádzajúci a týka sa predovšetkým dištančného vzdelávania. V súčasnosti sa na stránke univerzity uvádza, že temín „Learning and Technology" zahrňuje množstvo podobných termínov, ako sú vzdelávacie technológie, technology-enhanced learning, počitačom asistované vzdelávanie, vzdelávanie s IKT a eLearning [10].

Neznalost' politiky výskumu EU a terminológie $\mathrm{v}$ oblasti aplikácií IKT sa prenáša aj do praxe. Napr. autor príspevku má skúsenosti $\mathrm{s}$ takým prístupom oponentov, že prácu zameranú na TEL si pomýlili s eLearningom alebo jednoúčelovými záležitost’ami, ako sú pedagogické expertné a inteligentné vyučovacie systémy. Výsledkom takéhoto povrchného prístupu sú potom argumenty typu, že je „,nepripustné ignorovat' výsledky druhých a sústredit' sa len na určitú skupinu autorov, prípadne vedeckých škôl“. V danom prípade si treba uvedomit', že pri posudzovaní aplikácií TEL posudzovatel' nemôže porovnávat' veci podl'a nejakého subjektívneho pocitu, ale musí vždy vychádzat' z porovnania s horeuvedenými ciel'mi politiky výskumu EU pre TEL (ako bolo uvedené sú vždy $\mathrm{k}$ dispozícii $\mathrm{v}$ informačnom systéme CORDIS). Ak sa napr. v prieskume na európskych univerzitách zistilo, že najčastejšími nástrojmi TEL sú systémy manažmentu vzdelávania [2], tak je každému jasné, že nejde ani o eLearning ani o pedagogické expertné systémy. To sa dá nakoniec usúdit' aj z obrázkov 1 a 2 . K tomu je možno ešte dodat' aj to, že ak chce oponent vytknút' niekomu, že „,ignoruje“ druhých výskumníkov, tak potom títo výskumníci musia $\mathrm{v}$ danej oblasti aj pôsobit', čiže publikovat', pracovat' v projektoch $\mathrm{v}$ oblasti TEL, zúčastňovat' sa na konferenciách. V opačnom prípade je namieste otázka, či sa posudzovatel' vôbec vyzná v tom, čo posudzuje. Pre nezainteresovaných treba dodat', že podávanie projektov $\mathrm{v} 7$. rámcovom programe je vel'mi náročná záležitost'. Stačí už to, aby sa predkladatelia návrhov projektov čo len trocha odklonili od zadefinovaných ciel’ov výziev TEL a takýto návrh nemá šancu.

Dalším špecifickým problémom je, že v oblasti IKT, resp. výskumu TEL dominuje jednoznačne angličtina. Počítačové softvéry, programovacie jazyky, návody, renomované časopisy - to, všetko je výlučne $v$ angličtine. $\mathrm{Na}$ Slovensku napr. v súčasnosti neexistuje časopis výskumnej kategórie (v zmysle klasifikácie Ministerstva školstva), kde by sa dal uverejnit' príspevok v rodnom jazyku. Situáciu navyše st'ažuje aj to, že sa oblast' IKT rozvíja tak rýchlo, že „príliv“" nových anglických termínov nedokáže riešit' ani národná normalizácia. Ako príklad možno uviest' internetový marketing [11] alebo podnikovú inteligenciu [12]. V [12] sa vel'mi výstižne uvádza, že sa tu stretávajú dodávatelia softvéru, služieb, podnikoví manažéri, l'udia technických aj netechnických profesií, výskumníci a akademici, takže $v$ tomto babylone logický vznikajú nejasnosti v pomenovaní nových pojmov vyplývajúce $z$ nedostatočnej znalosti, odlišných záujmov jednotlivých strán a v našich pomeroch aj z dôvodu chýbajúcich ekvivalentov anglických pojmov.

Tu je dôležité pochopit', že informačné technológie sa vždy aplikujú pre nejakú odbornú oblast' a ak sa do nej integrujú, tak logicky nemajú svoju teóriu. Čiže neexistuje ani samostatná teória pre kategóriu TEL. Prioritne teda nemá význam riešit' za každú cenu exaktnost' pojmov a definícií (zvlášt' ked' IKT do nich riadne ešte neprenikla). Najdôležitejšie je pochopit' podstatu veci a preto je vždy užitočné, ak sa v dnešnej záplave informácií podarí nájst' kvalitný zdroj, z ktorého čitatel' rýchlo pochopí princípy. Na ilustráciu takých zdrojov možno uviest' [13] a [14], z ktorých čitatel' rýchlo pochopí špecifiká znalostného manažmentu na univerzitách a v podnikoch.

Dôležitost' terminologických problémov si uvedomuje aj komunita výskumníkov v oblasti TEL. Na ilustráciu možno uviest' open - archív TeLEarn. Jeho základ sa vytvoril v rámci projektu excelentnej siete 6.rámcového programu Kaleidoscope pre výskum voblasti TEL. V súčasnosti je podporovaný o.i. excelentnou siet'ou 7.rámcového programu Stellar (Sustaining Technology Enhanced Learning at a LARge scale). V rámci archívu sa zhromažd'ujú publikácie a vytvára sa tezaurus a slovník základných pojmov pre TEL. V súčasnosti je tam pre 18 jazykov, vrátane slovenčiny 
(http://www.tel-thesaurus.net/tel/sk/). A sú tam termíny aj v čínštine a kórejčine, čo nasvedčuje tomu, že prax si vyžaduje, aby sa učitelia a výskumníci v oblasti TEL vedeli dorozumiet'. Prevodným jazykom je tu samozrejme angličtina. So zmienenými terminologickými problémami súvisí aj otázka, ako správne citovat'. $\mathrm{Na}$ slovenských a českých univerzitách sa vyžaduje obvykle dodržiavanie normy ISO 690-2. Ak však pedagóg odpublikuje desiatky článkov v zahraničí, tak s prekvapením zistí, že takmer žiadny renomovaný časopis, resp. konferencie, túto normu nevyžadujú a takmer každý má svoje špecifické požiadavky. Tu je možné zmienit' sa aj o jednej vel'mi špecifickej záležitosti, ktorá je daná tým, že zahraniční vydavatelia limitujú počet strán príspevku. Pri prekročení tohoto limitu musí autor doplatit' obvykle 50-80 EUR za každú d’alšiu stranu. Ak by autor preferoval formálnu stránku citácií, vznikla by teda dilema, či má skrátit' odborný text alebo citovanú literatúru. Už zdravý sedliacky rozum hovorí, že stačí, ak je zdroj dostatočne identifikovatel'ný. To ostatné by malo byt' výlučne záležitostou knihovníkov - špecialistov (ako si to zapisujú do svojich databáz).

K otázke „prevahy“ odbornej angličtiny $\mathrm{v}$ oblasti IKT treba taktiež zdôraznit' skutočnost', že odborná práca, alebo vzdelávanie sa v inom než materskom jazyku predstavujú vysokú kognitívnu zát'až. Ortodoxné bazírovanie na akejsi čistote jazyka nie je preto vždy na mieste.

\section{Vedomosti a terminológia TEL}

Zhl'adiska tohoto príspevku je dôležité zmienit' sa aj o anglickom termíne „knowledge“. Tento termín je v angličtine vždy rovnaký, či už sa používa pre oblast' vzdelávania, IKT, vo filozofii, manažmente, psychológii a pod. V slovenčine sa však knowledge prekladá ako vedomosti, znalosti, a ak sa integruje informatika do vzdelávania, tak sa pod ním často rozumejú aj dáta a informácie. Jednou $\mathrm{z}$ inovatívnych IKT oblastí je „knowledge discovery in databases". $\mathrm{V}$ danom prípade ide o hl'adanie nejakého spoločného „znaku“ v databázach. Prekladá sa to však ako znalost', prípadne vedomost', hoci $\mathrm{v}$ terminológii databázových technológií by to niekto priradil $\mathrm{k}$ jednoduchým dátam alebo informáciam (tak ako to poznáme $\mathrm{z}$ databázových tabuliek). V oblasti manažmentu sa zase hovorí, že medzi dátami, informáciami a vedomostami (resp. znalost’ami) už existuje určitá hierarchia súvislostí vyjadrená napr. v modeli DIKW (pozri o.i. www.systems-thinking.org/dikw/dikw.htm).

Napriek tomuto stavu niektorí oponenti tieto terminologické nejednotnosti považujú za „závažné nedostatky“ hoci univerzálna definícia vedomosti napr. ani neexistuje. Neuvedomujú si však, že v inžinierskych disciplínach ide predovšetkým o podstatu veci a terminológia nie je prvoradá (najmä ak sa tvorí nejaký model, prototyp, nový softvér). Technici a vedci majú dokonca právo formulovat' si hypotézy a v nich zavádzat' svoje pracovné definície. Nakoniec vyžaduje sa to už aj od študentov pri bakalárskych prácach.

Autor tohto príspevku má osobnú skúsenost' s preberaním technických noriem ISO a CEN do sústavy STN, kde jednou z povinných činností bola konzultácia s Jazykovedným ústavom L'. Štúra. Pracovníčka ústavu vždy prízvukovala, že jazyk sa nesmie znásilňovat a ak má určitá odborná komunita svoju zaužívanú terminológiu, tak ju treba uprednostnit'. V tomto kontexte možno považovat' praktizovanie termínov, akým je napr. „odpamätovaná obrazovka“ za zbytočné znásilňovanie slovenčiny (myslí sa výstup na obrazovku - v angličtine screenshot).

Rôznorodost' prístupov $\mathrm{k}$ termínu „knowledge“ vidiet' aj z oxfordského slovníka. $\mathrm{V}$ n̆om sa pod týmto homonymom zahrňujú aj informácie uchovávané v systéme počitača; aj suma toho, čo je známe; aj faktá, informácie a zručnosti získané skúsenostou alebo vzdelávanim; aj porozumenie témy (http://oxforddictionaries.com/definition/english/ knowledge).

V prípade edukačného softvéru BIKE sa tento prezentuje ako editor pre dávkové spracovanie informácií a vedomostí. Takisto sa zmieňuje, že je založený na paradigme hromadného spracovávania vedomostí. Vychádza sa pritom z faktu, že prakticky v každej učebnici didaktiky sa vzdelávanie vysvetl'uje $\mathrm{v}$ zásade ako proces v ktorom sa poznatky a ćinnosti transformujú na vedomosti a zručnosti. A ked'že $\mathrm{v}$ danom prípade sa softvér BIKE využíva niekol'ko rokov na počítačovú podporu výučby, termín knowledge sa prekladá ako vedomost', čo by malo byt' korektné a každému zrozumitel'né.

\section{Aspekty počítačovej podpory s BIKE}

$\mathrm{Aj}$ ked' prínosy nasadenia počítačov pre vzdelávanie sú neodškriepitel'né, zabúda sa na to, že technológia sama o sebe „nemá didaktickú podstatu“ a jej úloha sa často preceňuje. $Z$ tohto hl'adiska je vel'mi zaujímavé tvrdenie Dillenbourga, ktorý v [15] špecifikuje ,štyri základné mýty" týkajúce sa preceňovania technológií vzdelávania, ktoré podl'a neho 
v súčasnosti strácajú svoju predchádzajúcu vysokú prestíž. Prvým je preceňovanie efektu použitia médii vo výučbe, druhým futuristický prístup ovzostupnom úspechu aplikácii eLearningu, tretím predpoklad, že najlepšie výsledky sa dosiahnu vtedy, ked' technológia je čo najviac podobná tradičnej praxi a štvrtým, že učitel' nie je ani „čarodejníkom" ani nejakým nezáväzným sprievodcom. Podl'a neho médiá sami o sebe ešte nezaručia pedagogické inovácie. Argumentuje aj tým, že ,nedostatky technológie nemožno donekonečna ospravedlňovat nedostatkom zručností učitel'ov". Títo podl'a neho majú dnes už vel'mi dobré počítačové zručnosti. Zaujímavé je aj tvrdenie, že imitovanie tradičného campusu alebo inštitúcie nepomáha učitel'om vo využití všetkých možností technológií (to je zrejme aj prípad Moodle alebo tzv. vzdelávacích balíkov). Obecné tvrdenie, že ak má pedagog učebné pomôcky $\mathrm{k}$ dispozícii, ešte neznamená, že budú skutočne aj prínosom pre osvojovanie si vedomostí a ich nevhodné použitie môže pôsobit' kontraproduktívne, čo platí aj pre technológiu [16].

Tieto výhrady voči technológií v prípade BIKE však ,nehrozia“, pretože sa vyvíjal na empirickom základe a využíval sa na generovanie elektronických učebných a študijných textov. Tento edukačný softvér, resp. jeho čast' Zápisník, ktorú používajú študenti, je sám o sebe súčasne aj editorom jednoduchých WEB-stránok. Jeho hlavnou silou je najmä to, že umožňuje užívatel'ovi interaktívne vytvárat' hypertextové alebo hypermediálne učebné pomôcky tak, ako ich definuje napr. Dostál v [16]. Nevyžadujú sa pritom žiadne špeciálne informatické zručnosti.

Z hl'adiska pochopenia podstaty funkcie softvéru BIKE je cenný teoretický článok Stolára, ktorý vymedzil v [17] tri paradoxy, čím vel'mi dobre vystihol situáciu na súčasnom trhu IKT. V paradoxoch zmieňuje informačný smog spôsobujúci pret’aženie jedinca, energiu mu uberajúce jazykové (ne)kompetencie (myslí sa zvládnutie informatiky, aby jedinec udržal krok s vývojom nepružného informatického prostredia) alebo st'ažené vyhl'adávanie a selekcia relevantných informácií, ktoré je ovplyvnené nerovnakou ontológiou rôznych domén. To podl'a neho má za následok, že aj špecialisti toho istého odboru si prestávajú rozumiet' (porovnaj s predchádzajúcou diskusiou o terminológii). Stolár zdôrazňuje, že spracovávanie vel'kého množstva informácií si vyžaduje iné prístupy a zdôrazňuje celoživotnú potrebu individualizácie vzdelávania. Ďalšie riešenie vidí v zjednodušení „spôsobu navigovania a ovládania natvrdlých sofistikovaných artefaktov" a transformácií na prirodzený jazyk jedinca a priblížit' sa tak $\mathrm{k}$ humanistickým princípom vzdelávania.

Práve potreba riešenia takýchto paradoxov je hnacou silou vývoja softvéru BIKE. Dá sa povedat', že na základnej úrovni užívatel'a sú vyriešené všetky tri paradoxy. Princíp BIKE je jednoduchý práve z toho dôvodu, že užívatel' používa prirodzený jazyk, ktorému sa musí stroj prispôsobit'. Čo sa týka meta - prístupu v ponímaní Stolára, zdá sa, že tento je zvládnutý tiež, prípadne aj to, že aplikácia je ešte d'alej, t.j. bližšie k človeku. BIKE má totiž zakomponované v sebe aj čiastočné prvky samoorganizácie vedomostí, čo sa dosahuje špeciálnym postupom indexovania. Aj užívatel'ské menu je riešené s určitým stupňom interaktivity. Uvedeným tvrdeniam nasvedčuje aj to, že niektorí zahraniční recenzenti chápali BIKE nielen ako edukačný softvér, ale zaradili ho aj do kategórie „knowledge management" (znalostný, resp. vedomostný manažment) a ,soft computing ${ }^{6}$ (patrí do tzv. umelej inteligence).

$\mathrm{V}$ tejto súvislosti bolo prelomom vo vývoji BIKE zadefinovanie vedomosti a sformulovanie paradigmy dávkového spracovania vedomostí. Táto bola publikovaná prvý krát v zahraničí $\mathrm{v}$ [18] a [19]. Definícia ,vedomosti“ je svojím spôsobom ešte vo vývoji. Základom je, že vedomost' sa chápe ako sada, resp. množina štruktúrovaných a neštruktúrovaných informácií $s$ určitým vzdelávacím obsahom, ktoré sú vložené do jedného riadku tzv. vedomostnej (databázovej) tabul'ky s určitou štruktúrou. Užívatel' si pritom sám volí spôsob, akým si vedomosti v tabul'kách rozvrhne. Tento jednoduchý prístup umožňuje využívat' ohromnú silu konvenčnej databázovej technológie a prirodzeným spôsobom modelovat' toky vedomostí medzi zdrojmi (internet, knowhow, e-nosič, tlačoviny) a vedomostnými tabulkami (ide hlavne o konštrukciu vzdelávacieho obsahu) a medzi tabul'kami a procesmi vo výučbe (ide o programovanie komunikácie a procesov $\mathrm{v}$ triede). Bližšie vysvetlenie implementovaných TEL aplikácií na konštrukciu vedomostí a automatizáciu výučby bakalárov presahuje rámec tohto príspevku. Detailnejší popis je uvedený v [20].

Riešenie počítačovej podpory, či už ide o TEL alebo eLearning sa vyznačuje obrovskou variabilitou potenciálnych prístupov. Nakol'ko vzdelávanie je l'ud'om vel'mi blízke, môžu sa metódy výskumu niekedy zdat' hlavne laikom ako menj vedecké, v porovnaní s tým, ked' sa 
počítače nasadzujú na neživé, technické systémy. V tejto súvislosti možno spomenút' zdroj [21], kde Chesler poukazuje na skutočnost', že dogma o akejsi správnej vedeckej metóde sa síce môže hodit určitej inštitúcii alebo vládnym agentúram pridelujúcim granty, avšak vôbec nemusi viest $k$ dobrému výskumu, t.j. výskumu, ktorý je validný a užitočný pre danú vedeckú komunitu $a$,svojpomocné hnutie“. V prípade vývoja BIKE zmienené zadefinovanie vedomostí, resp. sformulovaná paradigma ich dávkového spracovania sa môžu javit' pre niekoho terminologicky sporné, avšak tento prístup umožnil riešit' aj konverziu tzv. tacitných vedomostí na explicitné (bližšie v príspevku na konferencii ICL - IGIP zameranej na inžiniersku pedagogiku [22]). Obdobne sa BIKE prezentoval aj ako systém na spracovávanie vedomostí [23]. Hoci desiatky recenzentov nemali námietky voči koncepcii vedomostí $\mathrm{v}$ terminológii softvéru BIKE, v praxi došlo aj $\mathrm{k}$ situácii, že to oponenti označili za „terminologicky neprípustné“ (porovnaj s [17], že špecialisti toho istého odboru si prestávajú rozumiet', odhliadnúc od faktu, že vo výskume je osobná sloboda a nik nemá právo zakazovat' formulovat' hypotézy a definície).

\section{Príklady výstupov TEL do výučby}

Ako vidiet' už aj z obr. 1 a 2, výsledkom implementácie TEL je vel'ké množstvo rôznych kategórií výstupov do prostredia databázy alebo na internetový server fakulty. Systém podpory jednotlivých predmetov ilustruje obr. 3 na príklade predmetu Základy BOZP. Študent kliká na učebný text $\mathrm{v}$ l'avom navigačnom pruhu a v pravom okne sa zobrazujú výstupy - v danom prípade schéma, ktorú študent vypracoval $\mathrm{v}$ rámci semestrálnej práce; učivo pre meranie hluku (fotka $\mathrm{z}$ merania je $\mathrm{z}$ riešenia úlohy APVV) a materiál na posudzovanie rizík s linkami na internetové vzdelávacie materiály. V kontexte $\mathrm{s}$ paradoxami $\mathrm{v}$ [17] je $\mathrm{z}$ výstupu programu na obrazovku vidiet', že vedomosti (vzdelávací obsah) sú skoncentrované, navigácia medzi nimi jednoduchá a pre užívatel'a prirodzená, s minimálnym počtom rozhraní. V praxi sa ukázalo, že riešenie počítačovej podpory technických alebo informatických predmetov (Chémia a Programovacie jazyky) je niekol'konásobne jednoduchšie než predmetov všeobecnejšieho charakteru (Základy BOZP, Základy environmentalistiky, Semestrálne projekty). Z obr. 3 by malo byt' tretej osobe tiež

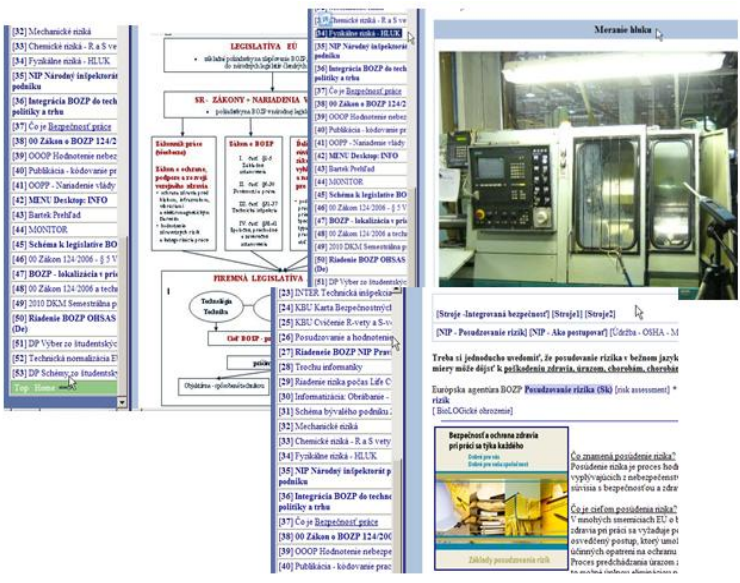

Obr. 3: Ukážka z tvorby študijných a učebných textov $v$ režime online alebo off-line

zrejmé, že takéto aplikácie zvyšujú kvalitu výučby (minimálne $z$ hl’adiska názornosti a rozmanitosti vzdelávacieho obsahu).

Ďalším poznatkom z implementácie TEL bolo zistenie, že ak sa má výučba automatizovat', treba počítaču ,pomôct t‘ tým, že učitel' musí hl'adat' spôsob, ako v čo najväčšej miere typizovat' alebo zjednotit' vzdelávací obsah a procesy. Z hl'adiska programovania to znamená, že učivo sa tým zmení na štruktúrované a pôvodne nedefinované procesy sa dajú popísat' sekvenciou čiastkových krokov. To radikálne zjednodušuje programovanie. Táto skúsenost' sa získala pri riešení počítačovej podpory písania semestrálnych prác. Pôvodný stav bol taký, že študenti si vyberali z desiatok tém a na konci semestra mali odovzat' prácu v rozsahu 5-10 strán. Výsledok bol však taký, že študenti odovzdávali práce o rozsahu 2030 strán a evidentne celé bloky textov mali stiahnuté a prekopírované $\mathrm{z}$ internetu. Išlo o prvákov bakalárov, ktorí si vôbec neboli vedomí, že ide o plagiarizmus. V rámci modelovania TEL sa zvolila cesta typizovat' všetko, čo sa dá. Riešenie spočívalo v tom, že sa zadala len jedna hlavná téma s piatimi subtémami a všetci študenti museli použit' jednotnú šablónu s povinnými kapitolami, napr. kapitola 3 bola určená na výpočty. Priebežné informácie museli dodávat' cez komunikačný kanál predmetu a sledovat' inštrukcie $\mathrm{k}$ písaniu práce počas celého semestra. Súčast'ou odovzdania práce bolo dodat' aj zvukový súbor, v ktorom počítač 
nahovorí po anglicky cca 1 min. obsah práce. Spojením zvukových súborov vznikol študijný audio-text, ktorý sa umiestnil na komunikačný kanál predmetu. Postup a výstupy ilustruje obr. 4, kde je vyznačené, že po kliknutí na [PHOTOSYNTHESIS - mp3] v priestore komunikačného kanála (študenti to volajú internetové fórum) zaznie zmienený cca pätminútový text, ktorý hovorí stroj - počítač. Prekvapujúcim výsledkom bolo, že sa takto viacmenej náhodne eliminoval prechádzajúci plagiarizmus. Taktiež do predmetu, ktorý sa vyučuje v slovenskom jazyku, sa implementovala angličtina a počítačové zručnosti (technológia Text-To-Speech a práca s audioformátmi).

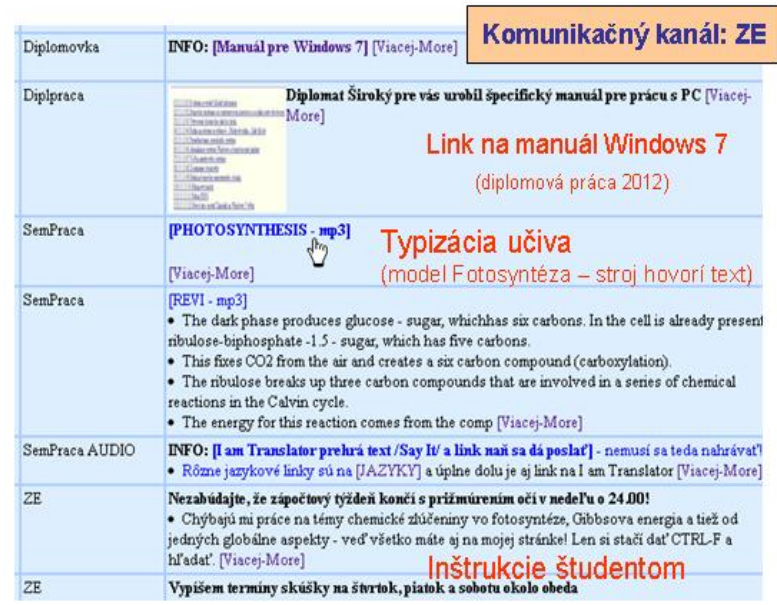

Obr. 4: Komunikačný kanál ZE - výber z riešenia TEL pre písanie semestrálnych prác

V tejto súvislosti treba zdôraznit' aj d'alší dôležitý aspekt $\mathrm{z}$ riešení TEL, a síce, že nie každá nová technológia je priamo vhodná pre výučbu. Učitelia, ktorí sa zaoberajú počítačovou podporou musia obvykle riešit' aj okruh týchto problémov. Ináč povedané, musia vymysliet'ako a či vôbec sa dá prispôsobit' nová technológia ich výučbe. V našom prípade možno uviest' ako príklad technológiu Speech Reckognition (počítač zapisuje hovorený text), ktorá sa skúšala aplikovat' na dávkové rešerše v BIKE. Táto sa zatial' neosvedčila. Jedným z dôvodov je aj to, že tieto softvéry si vyžadujú určitý čas, kým počítač rozpozná reč užívatel'a. No a vzhl'adom na to, že dostupné systémy sú nastavené na angličtinu, je natrénovanie počítača časovo náročné, hlavne ak agličtina nie je rodným jazykom učitel'a alebo študenta.

Preferovanie didakticko - riadeného prístupu pre TEL s typizáciou učiva a procesov prinieslo d’alší špecifický výsledok v tom, že vznikla potreba naprogramovat' virtuálne výpočtové prostredie. Dôvodom bol fakt, že študenti prváci majú slabšie vedomosti z chémie. Tie sú potrebné vo výučbe Základov environmentalistiky. Naprogramovala sa im preto tzv. chemická kalkulačka, ktorú museli študenti povinne použit' na výpočty do kapitoly 3 semestrálnej práce. Ide $\mathrm{v}$ podstate o e-zbierku vyriešených príkladov. Jej použitie ilustruje obr. 5 , kde je vyznačený postup výpočtu pre ideálny plyn. Študent sa po zadaní hesla dostane na výpočtový priestor fakultného servera a ako je vyznačené na obrázku, vyberie si niektorý z vyriešených príkladov. Podl’a potreby si potom precvičuje výpočet zadávaním vlastných vstupných hodnôt.

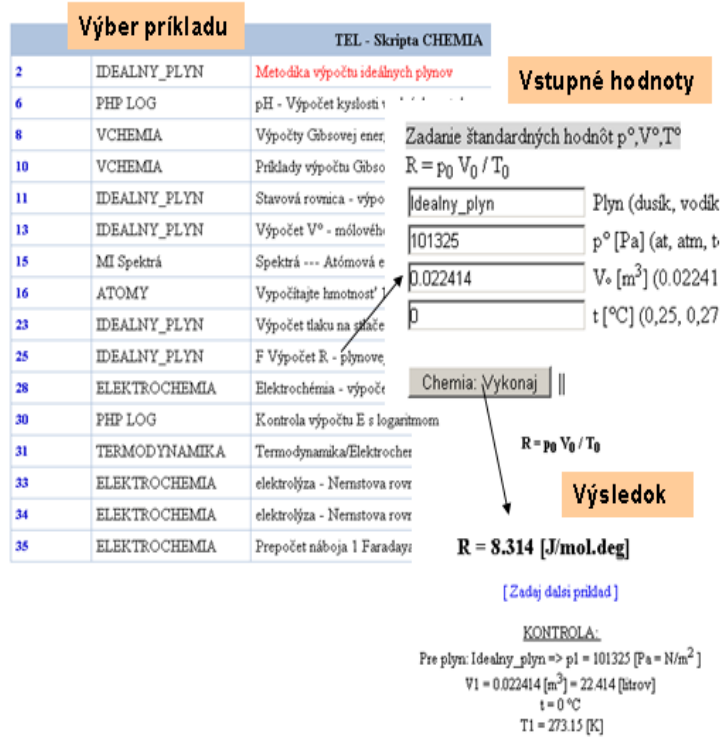

Obr. 5: Ukážka virtuálneho výpočtového priestoru-chemická kalkulačka

Okrem toho, že študenti - bakalári využivajú výstupy participačného akčného výskumu v rámci výučby niekol'kých predmetov, súčast'ou výskumu TEL bolo aj riešenie diplomových prác. Po pozitívnej skúsenosti využitia Zápisníka na jazykovú podporu v predmete Technická angličtina (jeho použitie zvládla učitel'ka jazyka $\mathrm{s}$ bežnými informatickými zručnost’ami), bolo zámerom zistit', či ho dokážu samostatne používat' aj študenti. Samotný BIKE je databázová aplikácia, ktorá má prvky tzv. umelej inteligencie a predstavuje prázdny systém, ktorý si užívatel' napíña podl'a potreby vedomost'ami. Ich úlohou bolo teda naplnit' aplikáciu vlastným pedagogickým alebo inžinierskym obsahom. Výstupom riešení diplomových prác obhájených v r. 2010-2011 na Katedre inžinierskej pedagogiky bol eLearningový materiál na výrobu závitov, riešenie podpory učebných štýlov a 
transferu kultúrneho vedecko-technického dedičstva zo zdrojov z predinternetového obdobia do výučby (súčast'ou bola digitalizácia odborných kníh). Obdobne v r. 2011-2012 študenti externisti samostatne riešili podporu jazykových a informatických zručností. Obr. 6 ilustruje tieto výstupy, ktoré sa sprístupnili bakalárom prostredníctvom komunikačného fóra. Učitelia aj bakalári môžu teraz tieto vzdelávacie materiály využívat'.

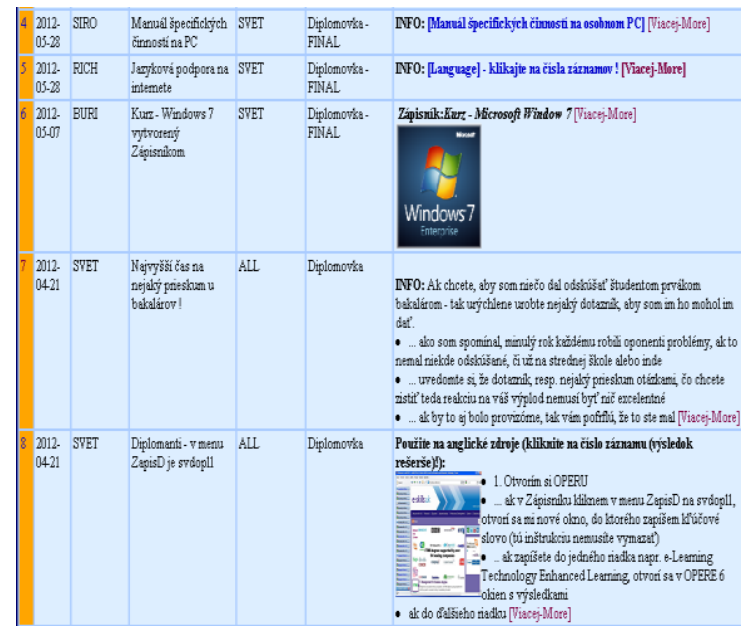

Obr. 6: Ukážka výstupov diplomových prác integrovaná do komunikačného fóra bakalárov

\section{Záver}

Článok priblížil výsledky dlhodobého výskumu implementácie tzv. technology enhanced learning do výučby bakalárov na Materiálovotechnologickej fakulte STU. Súčasne priblížil politiku EU pre IKT v tejto oblasti a diskutovali sa niektoré technologické, didaktické a terminologické aspekty. Prezentovali sa skúsenosti s počítačovou podporou výučby bakalárov získané na báze vývoja vlastného softvéru BIKE orientovaného na osobnú podporu učitel'a a činností, ktoré bežne vykonáva. To sa týka nielen konštrukcie učebných a študijných materiálov, komunkácie a procesov výučby $v$ triede, ale aj administrativnych, hodnotiacich a d'alšich súvisiacich činností. V danom prípade sa technológia prispôsobuje učitel'ovi, ako kl'účovej osobe vo vzdelávaní. Predprogramované edukačné prostredie BIKE je jeho ,partnerom“, ktorý mu pomáha činnosti automatizovat' a okrem zvýšenia produktivity zvyšovt' aj kvalitu výučby. Na rozdiel od súčasnej praxe, ktorá preferuje technologicko - riadený prístup k TEL, sa v článku zdôraznil didakticko - riadený prístup. Výstupmi z pilotných aplikácií do výučby bakalárov je systém TEL (online/off- line), ktorý okrem edukačného softvéru (BIKE, Zápisnik) tvorí vzdelávacie prostredie na fakultnom serveri sučebnými textami, knižnicami, komunikačnými kanálmi a virtuálnym výpočtovým prostredím, vrátane tútoriálov a testov. V súčasnosti sa počítačovej podpora výučby chápe ako automatizácia vzdelávacích procesov. Základom sú vedomosti, ktoré sú zadefinované. $Z$ z informatického hladiska sa sformulovala aj paradigma umožňujúca ich hromadné spracovávanie. Novým prvkom je typizácia a zjednocovanie učiva, komunikácie a procesov výučby. To umožnilo automatizovat' výučbu aj $\mathrm{v}$ prípadoch, ktoré by sa ináč s počítačom nedali riešit', t.j. ked' informácie, vedomosti a procesy nie sú dostatočne štruktúrované a definované (čo je vo výučbe väčšina prípadov). Vzhl'adom na sofistikovanost' a rozmanitost' procesov vzdelávania je preto d'alší vývoj v podstate nikdy nekončiaci príbeh. A nie zanedbatel'ným faktom je navyše aj to, že ide asi o jedno z najlacnejších riešení TEL, aké existujú na úrovni jednotlivca, pretože okrem softvéru BIKE stačí operačný systém Windows a pripojenie na internet $\mathrm{S}$ prideleným priestorom na fakultnom serveri.

Tento príspevok je súčast'ou riešenia projektu KEGA č. 047STU - 4/2012: Vybudovanie online učebne pre dynamické vzdelávanie študentov stredných a vysokých škôl z oblasti návrhu a výroby tvarovo zložitých súčiastok.

\section{Literatúra}

[1] ICT - Information and communication technologies Work programme 2013 [online]. [Cit.-2012-10-11]. Dostupné z: http://cordis. europa.eu/fp7/ict/docs/ict-wp2013-10-7-2013with-cover-issn.pdf.

[2] MATUSU, R., VOJTESEK, J., DULIK, T. Technology-enhanced learning tools in European higher education. In Proceedings of the 8th WSEAS international conference on Distance learning and web engineering. Santander, Cantabria, Spain, 2008.

[3] Paul S. Goodman et al. Technology Enhanced Learning: Opportunities for Change. Laurence Erlbaum Associates, Mahwah, NJ, USA, 2002. [4] DERRY, J. Technology - Enhanced Learning: A Question of Knowledge. Journal of Philosophy of Education. 2009, 42:505-519.

[5] MEIER, R. Global Trends in Engineering Education. 41st International Conference on Engineering Pedagogy, Villach, Austria, 2012. 
[6] LAURILLARD, D. Technology Enhanced Learning as a Tool for Pedagogical Innovation. Journal of Philosophy of Education, 2008, 42: 521-533.

[7] Balacheff, N., Ludvigsen, S., Jong, T., Lazonder, A., Barnes, S. (Eds.). Technology Enhanced Learning. Principles and Products. Springer, 2009, XXVI, 326 p.

[8] SVETSKÝ, Š. et al. Five years of research into technology-enhanced learning at the Faculty of Materials Science and Technology. In: Research papers Faculty of Materials Science and Technology Slovak University of Technology in Trnava. Vol. 19, No. 30 (2011), p. 105-114.

[9] ALLISON, L. Key issues in the design and delivery of technology-enhanced learning [online] London: Facet Publishing [Cit. 2012-04-11] Dostupné z: http://www.facetpubli shing.co.uk/ downloads/file/sample_chapters/developing_nle_C h4.pdf.

[10] Programme Specification for M.Sc. Education (Learning!and!Technology) [online]. Department of Education, University of Oxford. [Cit.-2012-11-11]. Dostupné z: http://www. Edu cation.ox.ac.uk/wordpress/wp-content/uploads/20 10/09/MScEducationLTProgSpec1213.pdf

[11] TUŠANOVÁ, A., PARALIČ, J. Príklad využitia webových technológií pre internetový marketing. 5th Workshop on Intelligent and Knowledge oriented Technologies WIKT 2010. Proceedings. 2010, Bratislava.

[12] KOVÁČ, J. Podniková inteligencia, analytika a proces objavovania znalostí $\mathrm{v}$ databázach. 5th Workshop on Intelligent and Knowledge oriented Technologies WIKT 2010. Proceedings. 2010, Bratislava.

[13] LAVRIN, A., ZELKO, M. Cez informačnú gramotnost' k manažmentu znalostí. Proceedings of the 8th International Conference on Systems Integration 2000, Prague, ISBN 80-245-0041-8. [14] KIDWELL, J. J., VANDER LINDE, K. M., JOHNSON, S. L. Applying Corporate Knowledge Management Practices in Higher Education. Gerald Berbom ed., Information Alchemy - Villey Company, 2001.

[15] DILLENBOURG, P. Integrating technologies into educational ecosystems. Distance Education, Routledge - Taylor \& Francis Group (2008), Vol. 29, No. 2, p.127-134. [16] DOSTÁL, J. Multimedia, hypertext and hypermedia teaching aids a current trend in education. Journal of Technology and Information Education. 2009, Olomouc - EU, Univerzita Palackého, Ročník 1, Číslo 2, s. 18 -
3. ISSN 1803-537X (print). ISSN 1803-6805 (online).

[17] STOLÁR, A. META-EDUCATION. 2009, Olomouc - EU, Univerzita Palackého. Journal of Technology and Information Education. 2009, Olomouc - EU, Univerzita Palackého, Ročník 1, Č́slo 1, s. 7 - 18. ISSN 1803-537X (print). ISSN 1803-6805 (on-line).

[18] SVETSKÝ, Š. et al. The Implementation of the Personalised Approach for Technology Enhanced Learning. Lecture Notes in Engineering and Computer Science, ISSN 20780958, Volume 2186, Issue 1, Year 2010, str. 321323. - registrovaný vo Web of Science.

[19] MORAVČÍK, O. et al. Experiences with the Personalised Technology Support for Engineering Education. In: Proceedings of the 2010 AaeE Conference. 2010, Australia, Sydney. ISBN 978-0-646-54610-0, s. 532-538.

[20] SVETSKÝ, Š. Praktické aspekty konštruovania vedomostí a automatizácie výučby $\mathrm{v}$ rámci technológiou zdokonal'ovaného vzdelávania a eLearningu. Trnava: STU v Bratislave MTF, 2012, 129 s. (habilitačná práca). [21] CHESLER, M. A. Participatory action research with self-help groups: An alternative paradigm for inquiry and action. American Journal of Community Psychology. 1991, 19, (5), p. 757-768.

[22] SVETSKÝ, Š., MORAVČÍK, O., ŠTEFÁNKOVÁ, J., SCHREIBER, P. IT Support for Knowledge Management within $R \& D$ and Education. In: ICL 2012 - 41st International Conference on Engineering Pedagogy, 26 - 28 September, Villach, Austria. IEEE Catalog Number: CFP1223R-USB. IEEE, 2012.

[23] SVETSKÝ, Š., MORAVČÍK, O., TANUŠKA, P., ŠTEFÁNKOVÁ, J., SCHREIBER, P., VAŽAN, P. The Particular Approach for Personalised Knowledge Processing," Advances in Computer Science, Engineering \& Applications. Advances in Intelligent and Soft Computing, Berlin Heidelberg: Springer - Verlag, 2012, Volume 166, pp. 937 -946.

\section{Ing. Štefan Svetský, Ph.D. \\ Detašované pracovisko Materiálovotechno- \\ logickej fakulty so sídlom v Trnave STU \\ Partizánska 131/2}

01851 Dubnica nad Váhom, SR

Tel: +421 42442 2375,

E-mail: stefan.svetsky@stuba.sk

Www pracoviska: www.mtf.stuba.sk 